\title{
Erratum to: Gene Editing, Gene Therapy, and Cell Xenotransplantation: Cell Transplantation Across Species
}

\author{
Nizar I. Mourad ${ }^{1} \cdot$ Pierre Gianello $^{1}$
}

Published online: 26 August 2017

(C) Springer International Publishing AG 2017

Erratum to: Curr Transpl Rep (2017)

https://doi.org/10.1007/s40472-017-0157-6

The original version of this article unfortunately contained a mistake. The caption of Figure 1 on the published version of the article was wrong. With this, the original article was corrected and the correct caption is now presented below.

Fig. 1 In vivo and in vitro insulin secretion from porcine islets. a, b Glucose $(\bigcirc)$ and insulin $(\bigcirc)$ were measured in plasma after intravenous glucose challenge $(0.5 \mathrm{mg} / \mathrm{kg})$ in piglets (a) and non-human primates $(N H P ; \mathbf{b})$. $\mathbf{c}$ In vitro insulin secretion from perifused piglet islets exposed to $1 \mathrm{mM}$ glucose $(G 1)$ then stimulated with $15 \mathrm{mM}$ glucose (G15). Potassium channel blocker, tolbutamide $(500 \mu \mathrm{M})$, then $30 \mathrm{mM} \mathrm{KCl}(K 30)$ were added to the perifusion medium as indicated on top of the figure. Values are means $\pm \operatorname{SEM}$ from $n=3-5$ intravenous glucose tolerance tests (IVGTTS) and $n=4$ different preparations for islet perifusions

The online version of the original article can be found at https://doi. org/10.1007/s40472-017-0157-6

Pierre Gianello

Pierre.Gianello@uclouvain.be

1 Pôle de chirurgie expérimentale et transplantation, Université catholique de Louvain, SSS/IREC/CHEX, Avenue Hippocrate, 55 - Bte B1.55.04, 1200 Brussels, Belgium 